\title{
The Properties of Virginiamycin-resistant Mutants of Bacillus subtilis
}

\author{
By C. COCITO AND G. FRASELLE \\ Department of General Microbiology and Molecular Genetics, \\ University of Louvain, Bruxelles I200, Belgium
}

(Received 24 July 1972; revised 22 November 1972)

\begin{abstract}
SUMMARY
Single components of virginiamycin $\mathrm{M}$ and $\mathrm{S}$ inhibit the growth of sensitive strains of Bacillus subtilis. The mixture of $\mathrm{M}$ and $\mathrm{S}$ halts completely the multiplication of double-sensitive organisms and of S-sensitive M-resistant mutants, but only partly inhibits growth of M-sensitive S-resistant cells, and is without effect on double-resistant mutants. Single virginiamycin components have essentially a bacteriostatic activity, whereas the association of $\mathrm{M}$ and $\mathrm{S}$ is lethal for doublesensitive bacteria as well as for S-sensitive M-resistant mutants. This lethal effect is a two-step process, which occurs without appreciable lysis. No bactericidal effect can be observed when S-resistant cells are incubated with a mixture of $\mathbf{M}$ and $\mathbf{S}$. The patterns of inhibition of protein synthesis in different mutants are similar to those of growth inhibition and viability loss: the latter effects are therefore consequences of the former. Virginiamycin $S$ can have different effects on protein synthesis: it enhances the action of $\mathbf{M}$ in S-sensitive cells but prevents the inhibitory action of $\mathrm{M}$ in S-resistant mutants. It can be concluded that both virginiamycin components interfere with growth, protein formation and cell viability. However, only the gene for S-sensitivity is essential (i) for the lethal action of the association of virginiamycin $\mathrm{M}$ and $\mathrm{S}$, (ii) for the inactivation of cells submitted to an alternate treatment with the two virginiamycin components and (iii) for rendering permanent the inhibition of protein synthesis.
\end{abstract}

\section{INTRODUCTION}

The peculiar feature of the antibiotic virginiamycin is that it contains two synergistic factors, $M$ and S (reviewed by Vazquez, 1967, and Pestka, 1972). Each component alone is capable of blocking reversibly the growth of sensitive organisms, whereas the combination of $\mathrm{M}$ and $\mathrm{S}$ induces a loss of viability (Cocito, I969 $a, b$; I97 I). A synergistic effect of $\mathrm{M}$ and S was also observed in eucaryotes (Cocito, Bronchart \& Van Pel, 1972; Van Pel, Bronchart, Kebers \& Cocito, I972; Van Pel \& Cocito, 1972).

Analysis of polypeptide synthesis in cell-free systems has pointed to the $50 \mathrm{~S}$ ribosomal subunit as the target of virginiamycin M (Cocito \& Kaji, I97I). The real target of the S component, as well as the mechanism by which this drug stops cell growth and protein synthesis, are still unknown.

A study of bacterial mutants, sensitive and resistant to each virginiamycin component, might help elucidate the mechanism of action of this antibiotic and the lethal effect of the association of the two components. The present work describes the biochemical and biological properties of such mutants. 


\section{METHODS}

Solutions and chemicals. Composition of media and buffers, and procedures for purification of the two virginiamycin components, were detailed in previous publications (Cocito, 1969a; 1971).

Isolation of mutants. All the resistant mutants employed in this work were isolated from the mutant $\mathrm{M}^{\mathrm{T}} \mathrm{S}^{\mathrm{I}}$, sensitive to both virginiamycin components. This mutant was obtained from the strain I68M of Bacillus subtilis, which turned out to be M-resistant S-sensitive.

Mutants $\mathrm{M}^{\mathrm{T}} \mathrm{S}^{\mathrm{I}}$ were produced by treatment with the mutagen $N$-methyl- $N^{\prime}$-nitro- $N$-nitrosoguanidine (MNNG), followed by selection with penicillin. Exponential $168 \mathrm{M}$ cells were incubated for $60 \mathrm{~min}$ with $50 \mu \mathrm{g} / \mathrm{ml}$ MNNG. Surviving cells were grown overnight in nutrient broth, treated with virginiamycin $\mathrm{M}(0 \cdot \mathrm{I} \mu \mathrm{g} / \mathrm{ml}, 3 \mathrm{~h})$ and penicillin (I000 u/ml, $3 \mathrm{~h}$ ). Surviving cells $(2 \%)$ were incubated with penicillinase, and colonies obtained after overnight growth in agar were replica-plated on agar supplemented with virginiamycin $\mathbf{M}$ $(20 \mu \mathrm{g} / \mathrm{ml})$. Other $\mathrm{M}^{\mathrm{T}} \mathrm{S}^{\mathrm{I}}$ mutants were produced by irradiation with u.v. and penicillin selection. For this purpose, suspensions of $168 \mathrm{M}$ cells in phosphate buffer were irradiated with a $15 \mathrm{~W} / \mathrm{GE} \mathrm{Hg}$ lamp, under conditions yielding $\mathrm{I} \%$ survivors.

From $\mathrm{M}^{\mathrm{I}} \mathrm{S}^{\mathrm{I}}$ cells, S-resistant mutants were prepared by MNNG treatment and selection in S agar $(20 \mu \mathrm{g} / \mathrm{ml})$. When a similar treatment was applied to production of M-resistant mutants, some cells were obtained which were capable of growing in M-containing agar, but were still inhibited by addition of $M$ during exponential growth. Such mutants were indicated as $M_{L}^{R} S^{I}$, as they proved to carry a 'late' resistance to $M$ and to be inhibited by $S$. Mutants carrying an 'early' resistance to $M\left(M_{E}^{R} S^{I}\right)$ were isolated by differential centrifugation. After treatment of $\mathrm{M}^{\mathrm{I}} \mathrm{S}^{\mathrm{T}}$ cells with MNNG $(200 \mu \mathrm{g} / \mathrm{ml}, 30 \mathrm{~min})$, surviving bacteria were grown for $30 \mathrm{~min}$ in YS medium before addition of virginiamycin $\mathbf{M}(50 \mu \mathrm{g} / \mathrm{ml})$. Growing and stationary cells were separated by low-speed centrifugation (I500 $\mathrm{g}$, I0 min); the pellet of 'heavy' cells was discarded, and the 'light' cells from the supernatant were spread on M-containing agar plates and tested for their ability of growth in YS medium containing virginiamycin $M($ Io $\mu \mathrm{g} / \mathrm{ml})$. Finally, from the three mutants $M_{E}^{R} S^{\mathrm{I}}, M_{L}^{R} S^{I}$ and $M^{I} S^{R}$ the corresponding double resistant mutants $\left(M^{R} S^{R}\right)$ were prepared by $M N N G$ treatment and selection in agar containing $\mathrm{M}$ and $\mathrm{S}$ ( $\mathrm{I} \mu \mathrm{g} / \mathrm{ml}$ each). Production of mutants can be summarized as follows:

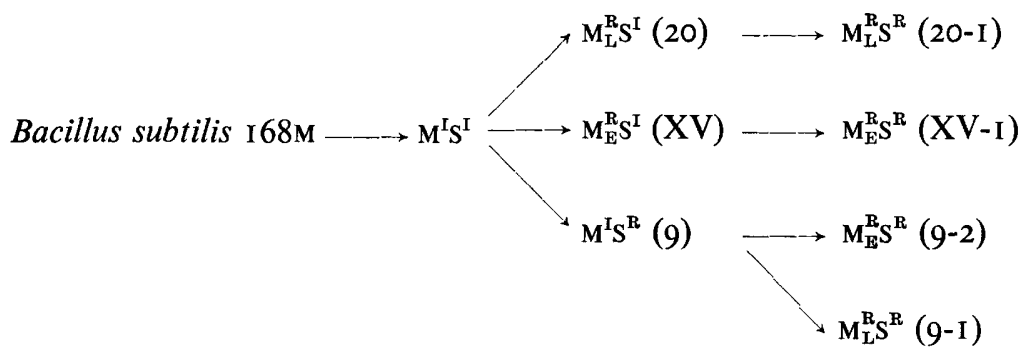

(where L means 'late' and E 'early', R 'resistance' and I 'sensitivity', and the corresponding numbers identify the mutants employed in this work). Mutation rates from sensitivity to 'late' $M$ resistance and to $S$ resistance were $\mathrm{IO}^{-6}$ to $\mathrm{IO}^{-7}$, and those to 'early' $\mathrm{M}$ resistance were approximately $10^{-10}$.

Measurement of growth and cell viability. Turbidity of the culture was measured by a Klett-Summerson Photocolorimeter equipped with a red filter 640 to $700 \mathrm{~nm}$ (I O.D. unit 


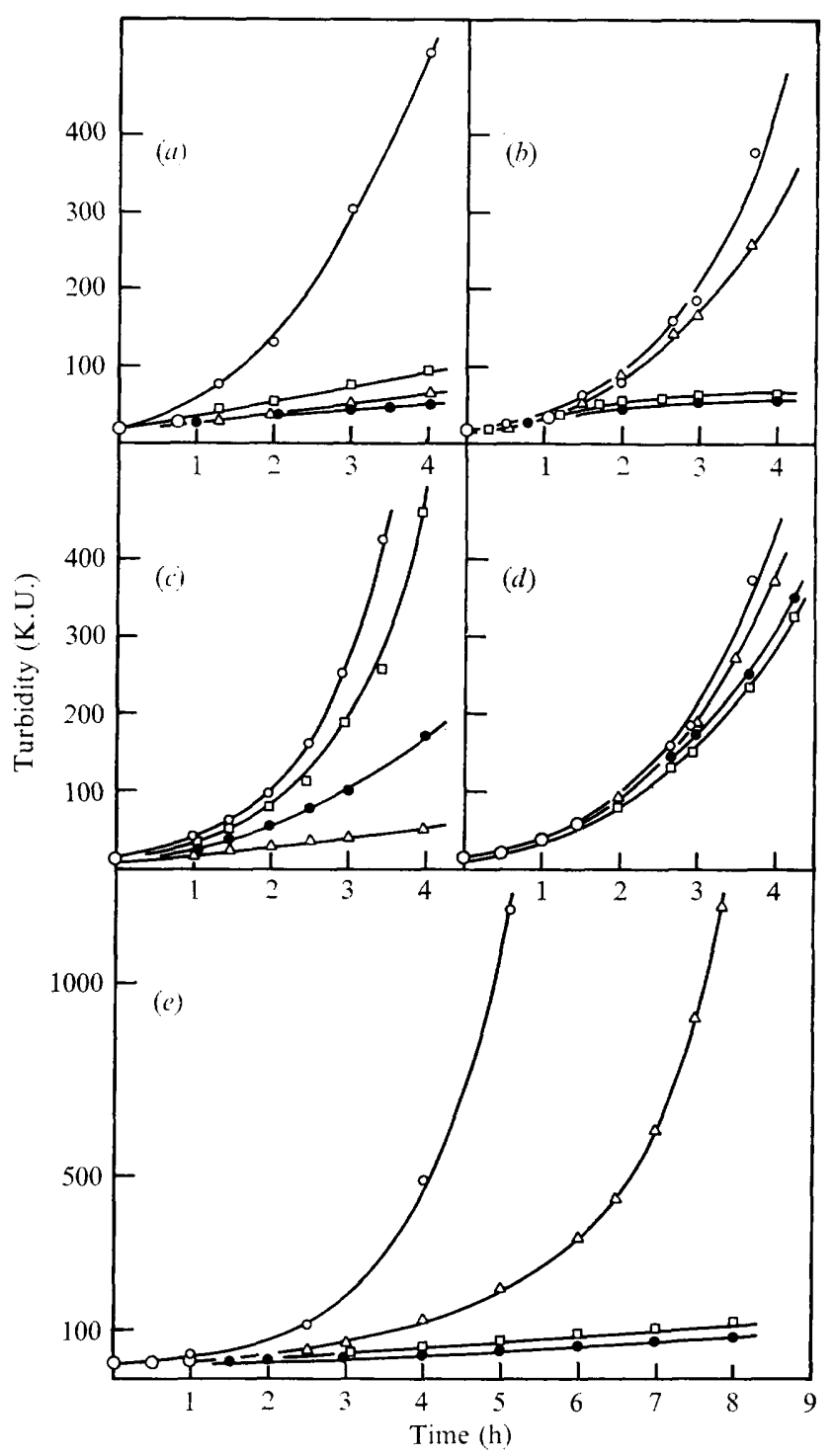

Fig. I. Growth of resistant mutants in the presence of virginiamycin. (a) $\mathrm{M}^{\mathrm{I}} \mathrm{S}^{\mathrm{I}}$ (no. 2); (b) $\mathrm{M}_{\mathrm{E}}^{\mathrm{R}} \mathrm{S}^{\mathrm{I}}$ (no. XV); (c) $\mathrm{M}^{\mathrm{I}} \mathrm{S}^{\mathrm{R}}$ (no. 9); $(d) \mathrm{M}_{\mathrm{E}}^{\mathrm{R}} \mathrm{S}^{\mathrm{R}}$ (no. 9-2); (e) $\mathrm{M}_{\mathrm{L}}^{\mathrm{R}} \mathrm{S}^{\mathrm{I}}$ (no. 2o). Growth conditions: $\bigcirc$, control; $\triangle$, virginiamycin $\mathrm{M}(\mathrm{I} \mu \mathrm{g} / \mathrm{ml}) ; \square$, virginiamycin S (I $\mu \mathrm{g} / \mathrm{ml}) ; \mathbf{O}, \mathrm{M}+\mathrm{S}(0 \cdot \mathrm{I}+0 \cdot \mathrm{I} \mu \mathrm{g} / \mathrm{ml})$. K.U. $=$ Klett units.

$=0.002 \times$ Klett units). Total cells were counted by use of a Bürker-type microchamber and a Zeiss microscope. Number and size of bacterial cells were also estimated, upon fixation with $3 \%$ formaldehyde by means of an impulsion-type counter (Coulter, model B). Colony forming ability was tested as previously described (Cocito, 1969a).

Kinetics of amino acid incorporation into proteins. To exponential cultures, a mixture of uniformly labelled ${ }^{14} \mathrm{C}$ amino acids containing $54 \mathrm{mCi}{ }^{14} \mathrm{C} /$ milliatom $\mathrm{C}$ (Radiochemical Centre, Amersham, Buckinghamshire) was added. At regular intervals, samples were withdrawn, and incorporation was stopped by addition of $0.5 \mathrm{M}$ ice-cold trichloroacetic acid 


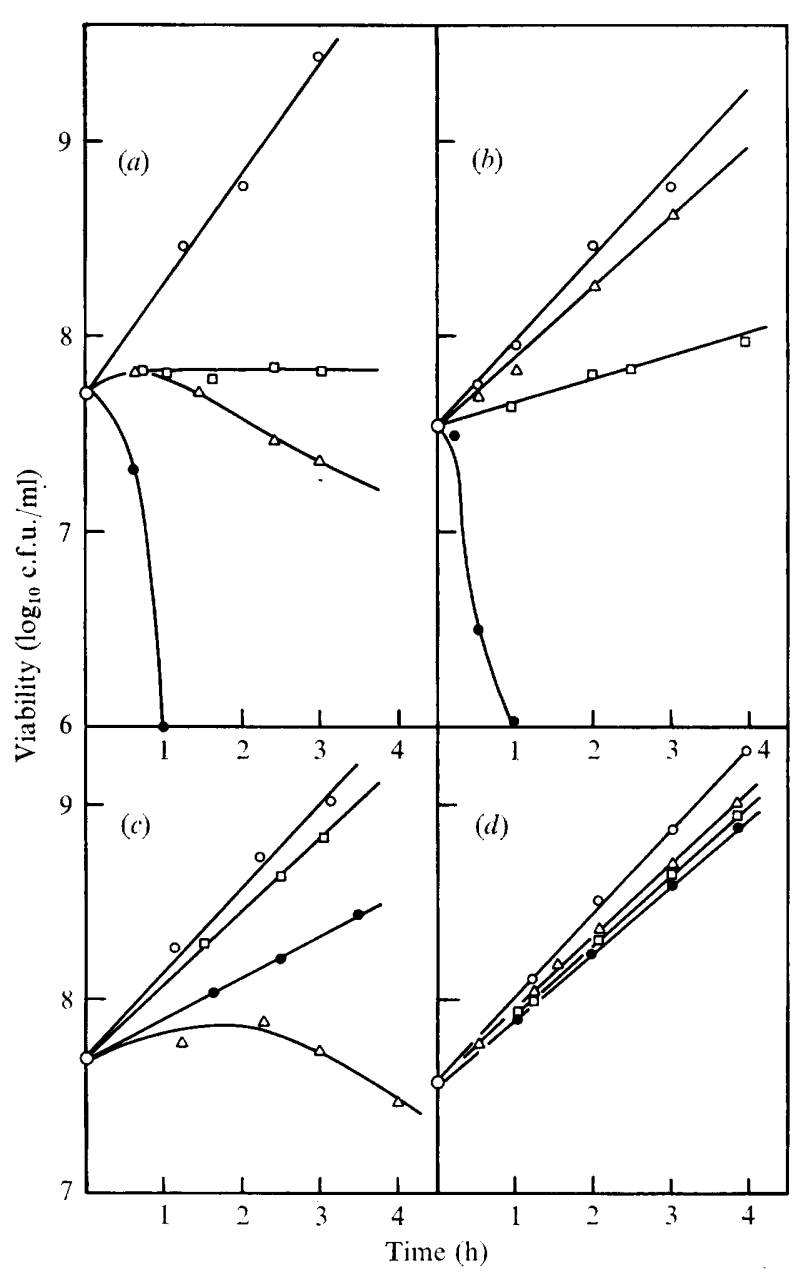

Fig. 2. Colony-forming ability as a function of the time of contact with virginiamycin $M$ and $S$. Types of mutants and growth conditions as in the legend for Fig. I.

(TCA). Precipitates were collected on millipore filters, washed with TCA, and counted in a liquid scintillation spectrometer, as previously described (Cocito, 1969a).

\section{RESULTS}

Growth of resistant mutants in the presence of virginiamycin. Growth of different mutants in the presence of virginiamycin $M$ showed the existence of three phenotypes, corresponding to sensitivity $\left(\mathrm{M}^{\mathrm{I}}\right)$, early $\left(\mathrm{M}_{\mathrm{E}}^{\mathrm{R}}\right)$ and late $\left(\mathrm{M}_{\mathrm{L}}^{\mathrm{R}}\right)$ resistance (Fig. I $\left.a, b, e\right) . \mathrm{M}_{L}^{\mathrm{R}} \mathrm{S}^{\mathrm{I}}$ mutants were inhibited at first by the drug; their growth resumed after a lag of about $4 \mathrm{~h}$, and continued since then at an almost normal rate (Fig. I $e$ ). $\mathrm{M}^{\mathrm{I}} \mathrm{S}^{\mathrm{R}}$ and $\mathrm{M}_{\mathrm{E}}^{\mathrm{R}} \mathrm{S}^{\mathrm{R}}$ multiplied equally well in the presence as in the absence of virginiamycin $\mathrm{S}$ (Fig. $\mathrm{I} c, d$ ).

Treatment with a mixture of $\mathrm{M}$ and $\mathrm{S}$ blocked completely the multiplication of all S-sensitive mutants $\left(\mathrm{M}^{\mathrm{I}} \mathrm{S}^{\mathrm{I}}, \mathrm{M}_{\mathrm{E}}^{\mathrm{R}} \mathrm{S}^{\mathrm{I}}, \mathrm{M}_{\mathrm{L}}^{\mathrm{R}} \mathrm{S}^{\mathrm{I}}\right.$ ) (Fig. I $a, b, e$ ). On the contrary, the growth of 


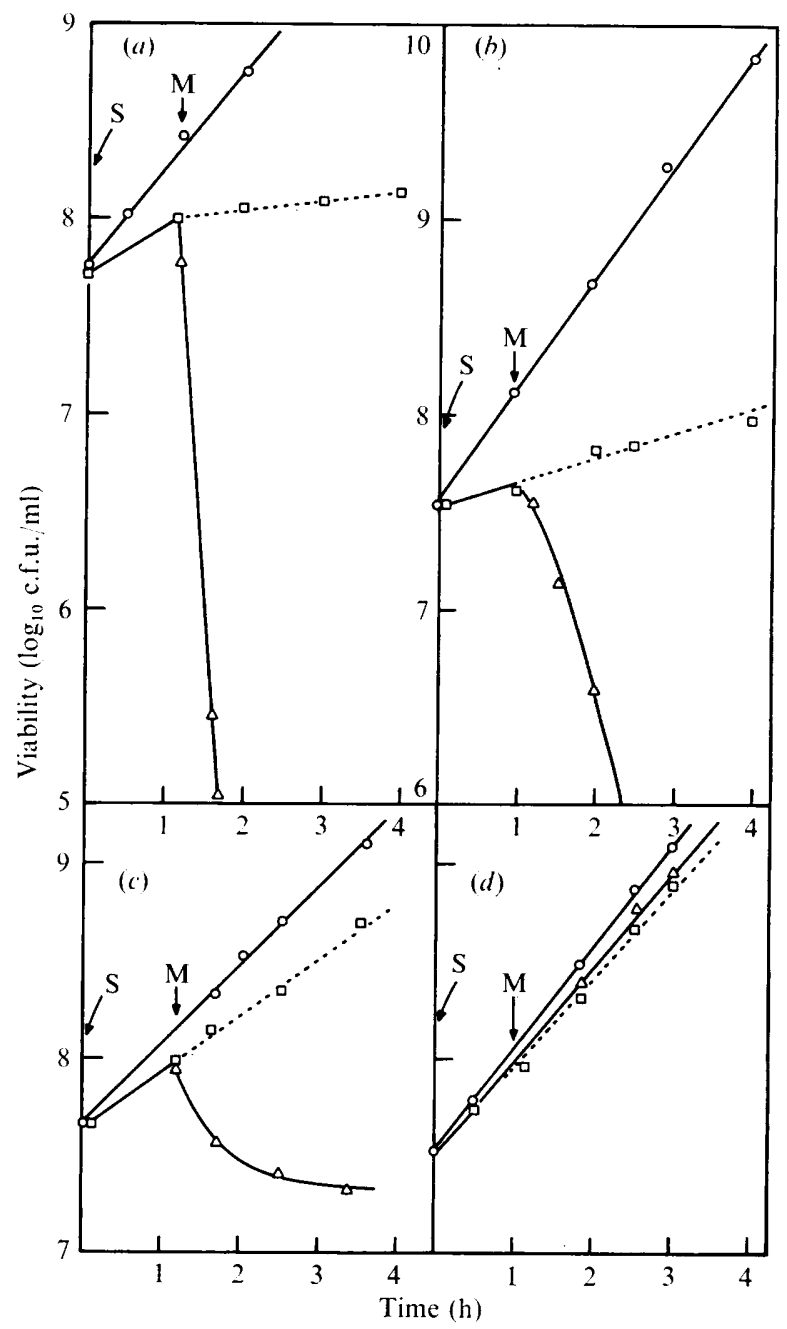

Fig. 3. Cell viability after alternate treatment with the two virginiamycin components. Types of mutants as in the legend for Fig. I. Experimental conditions: growth for one generation in the presence $(\square)$ or in the absence $(O)$ of virginiamycin $S(1 \mu \mathrm{g} / \mathrm{ml})$. Transfer of $S$-treated cells to media containing either $\mathbf{I} \mu \mathrm{g} / \mathrm{ml}$ virginiamycin $\mathbf{M}(\triangle)$, or none $(\square)$.

S-resistant mutants was partly inhibited $\left(\mathrm{M}^{\mathrm{I}} \mathrm{S}^{\mathrm{R}}\right)$, or not inhibited at all $\left(\mathrm{M}_{\mathrm{E}}^{\mathrm{R}} \mathrm{S}^{\mathrm{R}}\right)$ (Fig. I $\left.c, d\right)$ by $\mathrm{M}+\mathrm{S}$.

It can be concluded that both virginiamycin components inhibit the growth of bacteria, and that a very low concentration of the mixture of $\mathrm{M}$ and $\mathrm{S}$ suppresses the multiplication of sensitive cells.

The loss of viability caused by the antibiotic. Viability of $\mathrm{M}$-sensitive cells decreased slowly in the presence of virginiamycin M (Fig. 2a), whereas no drop of viability was observed in S-sensitive cells incubated with virginiamycin S (Fig. 2a,b). On the contrary, incubation with a mixture of $M$ and $S$ caused a sharp decrease of viability of $M^{I} S^{I}$ and $M_{E}^{R} S^{I}$ mutants (Fig. 2a,b). All the S-resistant cells, however, whether M-sensitive or M-resistant, showed no viability loss (Fig. $2 c, d$ ). 


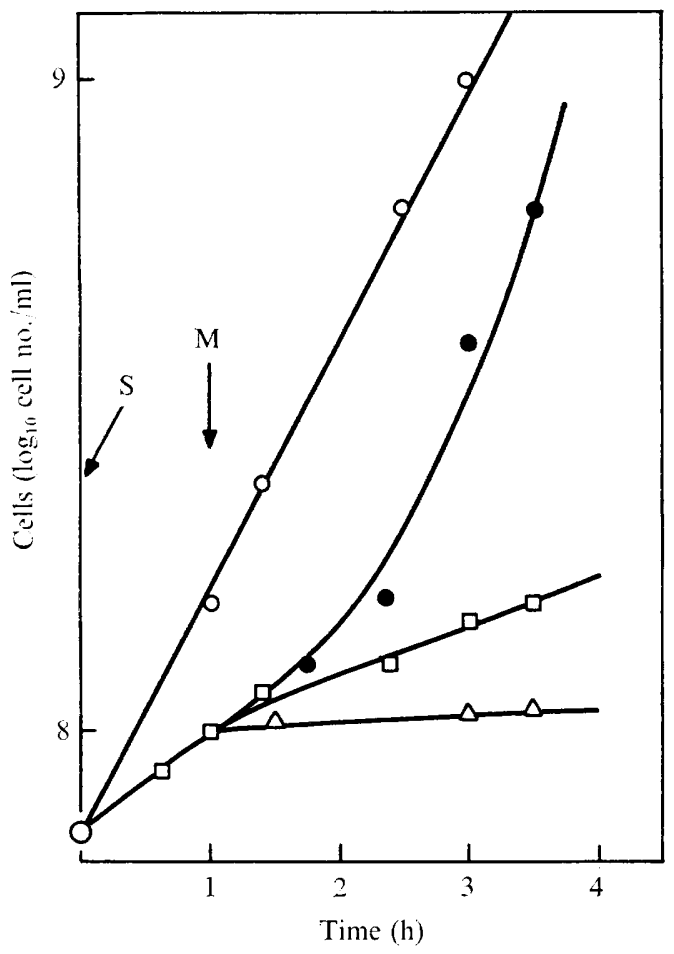

Fig. 4. Total cell count after alternating treatment with both components of virginiamycin. Doublesensitive mutants $M^{\mathrm{I}} \mathrm{S}^{\mathrm{T}}$ (no. 2) were grown for one generation in the presence ( $\square$ ) or in the absence (O) of virginiamycin $\mathbf{S}(\mathrm{I} \mu \mathrm{g} / \mathrm{ml})$. S-treated cells were divided into three samples, which were transferred to media containing either virginiamycin $\mathrm{S}(\mathrm{I} \mu \mathrm{g} / \mathrm{ml})(\square)$ or virginiamycin $\mathrm{M}(\mathrm{I} \mu \mathrm{g} / \mathrm{ml})$ $(\triangle)$ or neither $(\bullet)$. Cell number was evaluated in a Coulter Counter.

This indicates that the killing effect of the two virginiamycin components cannot be expressed in the absence of the S sensitivity gene.

The effect of alternate treatments with the two components. When the double-sensitive mutant $\mathrm{M}^{\mathrm{I}} \mathrm{S}^{\mathrm{I}}$ was incubated with one virginiamycin component and then transferred to fresh medium containing the other factor, there was a rapid drop in cell viability, which mimicked that induced by a mixture of $\mathrm{M}$ and $\mathrm{S}$ (Fig. $3 a$ ). Moreover, a rapid decrease of viability occurred in M-resistant S-sensitive cells $\left(\mathrm{M}_{E}^{\mathrm{R}} \mathrm{S}^{\mathrm{I}}\right.$ ) (Fig. $3 b$ ), but not in M-sensitive S-resistant cells $\left(M^{I} S^{R}\right.$ ), after either $M \rightarrow S$ or $S \rightarrow M$ treatments (Fig. $3 c$ ). This again shows that the synergistic effect of $M$ and $S$ requires the presence of the gene for S-sensitivity.

In all cases of decrease in cell viability, subsequent to a treatment with both virginiamycin components, turbidity of the cultures (not shown) and total cell number (Fig. 4) did not decrease.

Peptide bond formation in the presence of virginiamycin. It was shown previously that in wild-type bacteria incubated for short periods with virginiamycin, the incorporation of amino acids is blocked, whereas labelled precursors are incorporated at normal rate into polyribo- and polydeoxyribonucleotides (Cocito, I969a). To correlate the effects of virginiamycin on growth and protein synthesis, the kinetics of incorporation of labelled amino acids into polypeptides was followed in sensitive and resistant mutants.

As expected, single virginiamycin components blocked very rapidly protein formation in sensitive micro-organisms (Fig. $5 a-c$ ). Moreover, the association of $\mathrm{M}$ and $\mathrm{S}$ had a far 


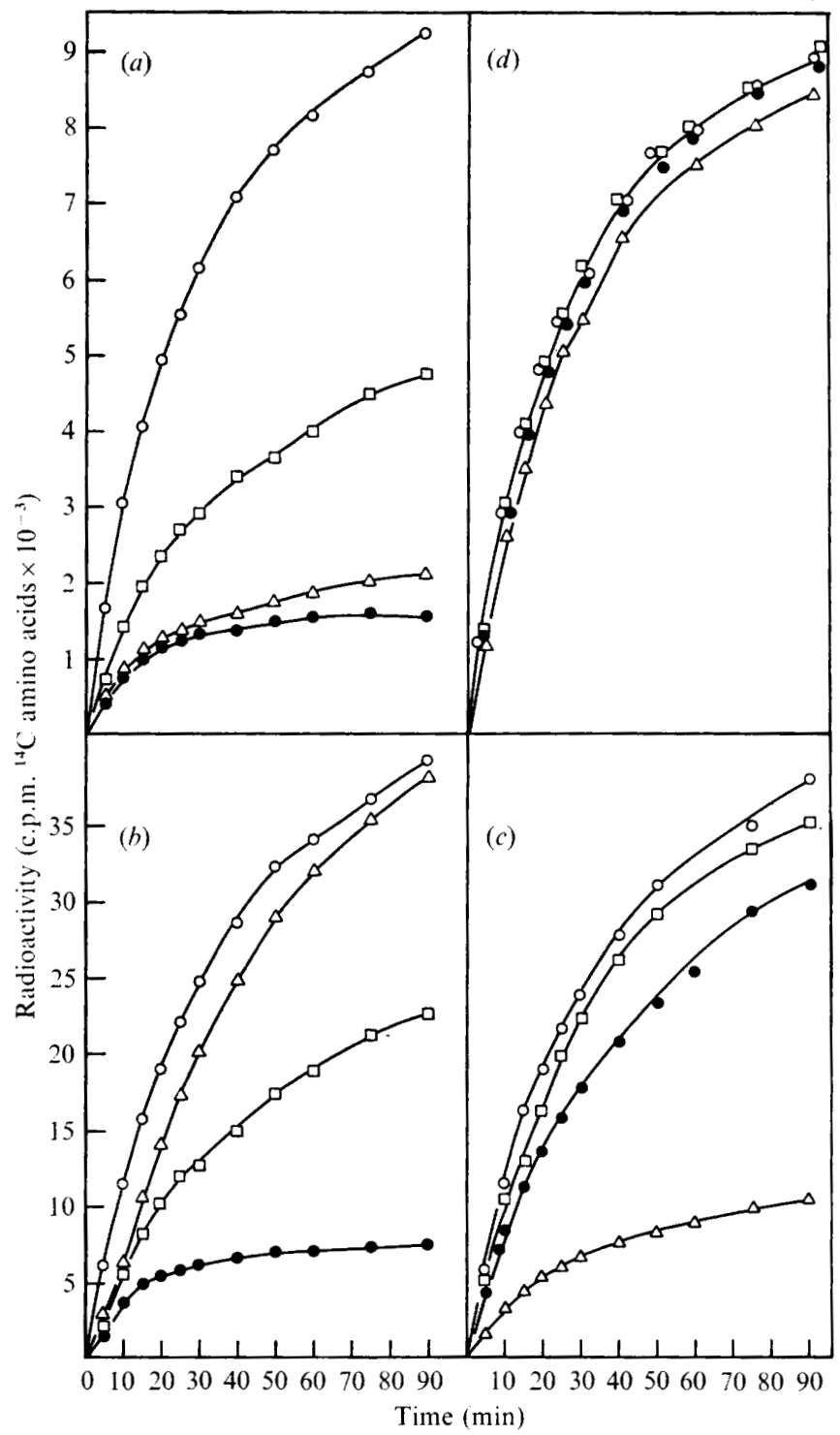

Fig. 5. Amino acid incorporation into polypeptides, in different mutants, in the presence of virginiamycin. Exponential cultures were treated with virginiamycin and labelled 5 min later with $\left[{ }^{14} \mathrm{C}\right]$ amino acids; radioactivity incorporated into proteins was measured. $(a) \mathbf{M}^{\mathrm{I}} \mathbf{s}^{\mathrm{I}},(b) \mathbf{M}_{\mathrm{E}}^{\mathrm{R}} \mathrm{S}^{\mathrm{I}},(c) \mathbf{M}^{\mathrm{I}} \mathbf{s}^{\mathrm{R}},(d) \mathrm{M}^{\mathrm{R}} \mathbf{S}^{\mathrm{R}}$. Virginiamycin: $\bigcirc$, none; $\triangle, \mathrm{I} \mu \mathrm{g} \mathrm{M} / \mathrm{ml} ; \square, \mathbf{I} \mu \mathrm{g} \mathrm{S} / \mathrm{ml} ; 0,0.05 \mu \mathrm{g} \mathrm{M}+\mathrm{S} / \mathrm{ml}$. Specific activities: $(a)$ and $(d) 0.125 \mu \mathrm{Ci}\left[{ }^{14} \mathrm{C}\right]$ amino acids $/ 0.400 \mathrm{mg}\left[{ }^{12} \mathrm{C}\right]$ amino acids $/ \mathrm{ml} ;(b)$ and $(c) 0.050 \mu \mathrm{Ci} / 0.400 \mathrm{mg}$.

higher inhibitory power than that of separate factors, in all S-sensitive mutants (Fig. $5 a, b$ ). Unexpectedly, however, the association of $\mathrm{M}$ and $\mathrm{S}$ had no inhibitory effects in M-sensitive S-resistant mutants (virginiamycin $\mathbf{M}$ alone blocked protein synthesis in these microorganisms) (Fig. $5 c$ ).

It can be concluded that virginiamycin $S$ has an opposite effect on the M-mediated inhibition of peptide bond formation, depending on the gene for $\mathrm{S}$ sensitivity: in S-sensitive cells, $S$ potentiates the effect of $M$, and in S-resistant cells, $S$ prevents it. 


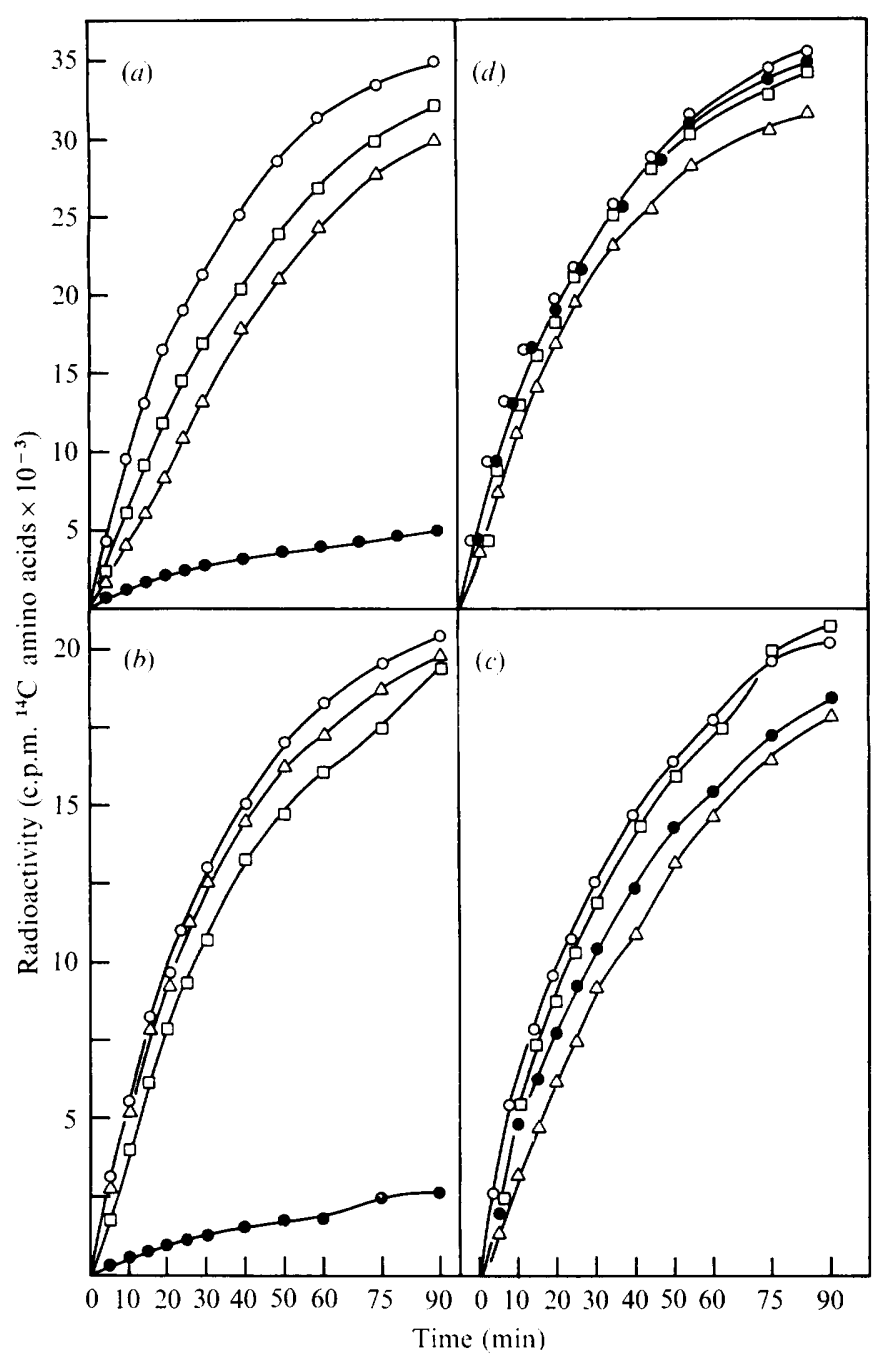

Fig. 6. Protein synthesis in antibiotic-free medium after treatment with virginiamycin. Cells were incubated with virginiamycin for $30 \mathrm{~min}$, harvested, washed, and transferred to antibiotic-free medium. $\left[{ }^{14} \mathrm{C}\right]$ amino acids were added, and the radioactivity incorporated into proteins was determined. $(a) \mathbf{M}^{\mathbf{I}} \mathbf{S}^{\mathrm{I}},(b) \mathbf{M}_{\mathrm{E}}^{\mathrm{R}} \mathbf{S}^{\mathrm{I}},(c) \mathbf{M}^{\mathrm{I}} \mathbf{S}^{\mathbf{R}},(d) \mathbf{M}^{\mathbf{R}} \mathbf{S}^{\mathbf{R}}$. Virginiamycin: $\bigcirc$, none; $\triangle, \mathrm{I} \mu \mathrm{g} \mathrm{M} / \mathrm{ml} ; \square, \mathrm{I} \mu \mathrm{g} \mathrm{S} / \mathrm{ml}$; $0,0.05 \mu \mathrm{g} \mathrm{M}+\mathrm{S} / \mathrm{ml}$. Specific activities: $(a)$ and $(d) 0.050 \mu \mathrm{Ci}\left[{ }^{14} \mathrm{C}\right]$ amino acids $/ 0.400 \mathrm{mg}\left[{ }^{12} \mathrm{C}\right]$ amino acids $/ \mathrm{ml} ;(b)$ and $(c) 0.025 \mu \mathrm{Ci} / 0.400 \mathrm{mg}$.

The reversibility of protein inhibition. To disclose a possible relationship between peptide bond formation and cell viability, the reversibility of protein inhibition by virginiamycin was investigated. Different mutants were treated with virginiamycin, and then transferred to antibiotic-free medium containing labelled amino acids. Likewise, peptide formation was followed in cells which were submitted to an alternate treatment with $\mathrm{M}$ and $\mathrm{S}$ before transfer to medium without antibiotics.

In double-sensitive mutants treated with either $\mathrm{M}$ or $\mathrm{S}$, protein synthesis resumed as soon as the inhibitors were removed. When cells were incubated with a mixture of $M$ and $S$, however, the ability to incorporate amino acids into polypeptides was not restored by the 


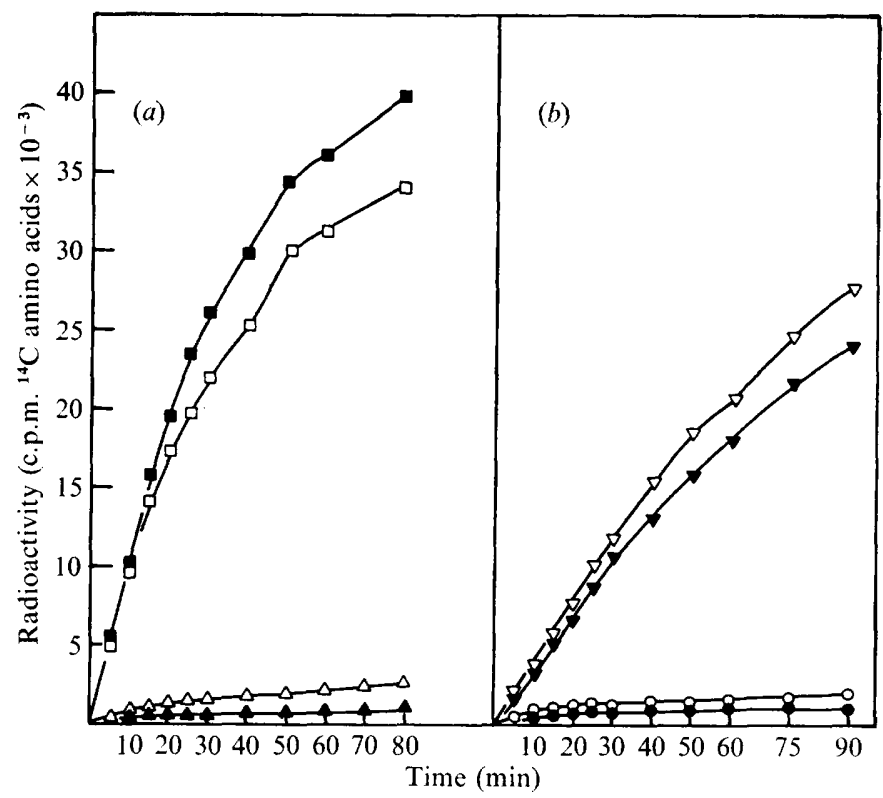

Fig. 7. Inhibition of peptide bond formation after alternate treatment with the two virginiamycin components. Cells were incubated for $20 \mathrm{~min}$ with one virginiamycin component $(1 \mu \mathrm{g} / \mathrm{ml})$, washed, treated with the other component ( $\mu \mathrm{g} / \mathrm{ml}$ ), washed, and transferred to antibiotic free medium. $\left[{ }^{14} \mathrm{C}\right]$ amino acids were added, and the radioactivity incorporated into proteins was determined. (a) $\mathrm{M}^{\mathrm{I}} \mathrm{S}^{\mathrm{I}}\left(\triangle\right.$ and $\Delta$ ) and $\mathrm{M}_{\mathrm{E}}^{\mathrm{R}} \mathrm{S}^{\mathrm{R}}(\square$ and $\boldsymbol{\square}) ;(b) \mathrm{M}_{\mathrm{E}}^{\mathrm{R}} \mathrm{S}^{\mathrm{I}}\left(\bigcirc\right.$ and $\bullet$ ) and $\mathrm{M}^{\mathrm{I}} \mathrm{S}^{\mathrm{R}}(\nabla$ and $\nabla)$. Virginiamycin treatment: open symbols, I $\mu \mathrm{g} \mathrm{M} \rightarrow \mathrm{I} \mu \mathrm{g} \mathrm{S}$; closed symbols, I $\mu \mathrm{g} \mathrm{S} \rightarrow \mathrm{I} \mu \mathrm{g} \mathrm{M}$. Specific activities:

(a) $2 \mu \mathrm{Ci}\left[{ }^{14} \mathrm{C}\right]$ amino acids $/ 0.400 \mathrm{mg}\left[{ }^{12} \mathrm{C}\right]$ amino acids $/ \mathrm{ml} ;(b)$ I $\mu \mathrm{Ci} / 0 \cdot 400 \mathrm{mg}$.

removal of the antibiotics (Fig. 6a). Similar behaviour was shown by M-resistant S-sensitive mutants (Fig. 6b). On the contrary, no permanent effect was observed in S-resistant cells, whether M-sensitive (Fig. 6c) or M-resistant (Fig. 6d).

The effect of alternate treatment with $\mathrm{M}$ and $\mathrm{S}$ on the kinetics of amino acid incorpor ation into polypeptide was similar. In S-sensitive cells, the block of protein synthesis was permanent, whereas no such effect was observed in S-resistant mutants (Fig. 7a, $b$ ).

The obvious conclusion is that the association of virginiamycin $\mathbf{M}$ and $\mathrm{S}$, as well as alternate treatment with the two factors, induce a permanent block of the protein synthesizing machinery; such effect appears only when the gene for S sensitivity is present.

\section{DISCUSSION}

It was reported previously (Cocito, I969a) that single virginiamycin components have a bacteriostatic effect, whereas their association is lethal. This work was done with the wildtype Bacillus subtilis strain I68, and the period of observation was restricted to less than $3 \mathrm{~h}$. Further investigations, with different strains and for longer periods, showed that the viability of sensitive cells incubated with either $M$ or $S$ depends on (i) the strain itself, (ii) the presence of other metabolic blocks, and (iii) the time of contact with the inhibitor. Thus, for example, the strain I68/2 loses slowly its viability in the contact with $\mathrm{S}$, as does the mutant $\mathrm{M}^{\mathrm{T}} \mathrm{S}^{\mathrm{I}}$ in the presence of $\mathrm{M}$ (cf. Fig. $2 a$ ). In this connexion it must be recalled that the double-sensitive mutant $\mathrm{M}^{\mathrm{I}} \mathrm{S}^{\mathrm{I}}$ employed in our experiment is not the wild-type. Pre- 
sumably, during evolution, a phenotype carrying a 'late' $M$ resistance accumulated, because it conferred selective advantages over the phenotype of $\mathrm{M}$-sensitive micro-organisms.

The loss of viability occurring in the presence of both virginiamycin components is a quite different phenomenon; in this case, about $90 \%$ of the sensitive organisms are killed within one generation time. Such a high rate of inactivation occurs only in $M^{I} S^{I}, M_{E}^{R} S^{I}$ and $\mathbf{M}_{\mathrm{I}}^{\mathrm{R}} \mathrm{S}^{\mathrm{I}}$ mutants. On the contrary, none of the S-resistant mutants is inactivated upon incubation with $M+S$. Obviously, the $S^{R}$ gene prevents the killing power of the two virginiamycin components. The mechanism of the lethal action of this antibiotic is still under investigation. Working with the strains $168 / 2$ and $168 / 6$ of Bacillus subtilis, it was observed that cells treated with $\mathrm{M}+\mathrm{S}$ do not synthesize ribosomes after transfer to antibiotic-free media (Cocito, I97I). We may then suppose that S-sensitive mutants are killed by a mixture of $\mathrm{M}$ and $\mathrm{S}$ because they lose permanently the capacity of making ribosomes. That this is probably the case is indicated by more recent data (Cocito, I973).

A priori, the loss of viability of a bacterial culture could be due either to a block of cell division, or to cell lysis. The latter occurs very easily in Bacillus subtilis, owing to the defective prophages carried by many strains of this organism. The activation of one such phage has been investigated by Okamoto et al. (1968). In our case, however, turbidimetric estimates and total cell counts exclude the possibility of lysis. Hence, a permanent block of cell division is responsible for the loss of cell viability after treatment with both virginiamycin components.

We have reported already that single virginiamycin components inhibit protein formation in wild-type Bacillus subtilis (Cocito, I969a), and similar observations were made by others with the related antibiotics mikamycin (Yamaguchi \& Tanaka, 1964), vernamycin (Ennis, I965a) and streptogramin (Vazquez, I966). Data presented in the present work confirm these reports and show that the target of factors $M$ and $S$, in all sensitive mutants, is peptide bond formation. $M$ and $S$ apparently have quite similar overall effects; in both cases, 'freezing' of polysome structures and prolongation of the half-life of mRNA were observed (Cocito, 197I). A similar effect was described in bacteria treated with chloramphenicol (Fan, Higa \& Levinthal, 1964). This indicates that single virginiamycin components stop the elongation of polypeptide chains with the translational units being held together. Detection of labelled virginiamycin $\mathrm{M}$ and $\mathrm{S}$ in the polyribosomes (Cocito, 1971), and results with cell-free systems (Laskin \& Chan, 1964; Ennis, 1965b; Cocito \& Kaji, I97I), agree with this interpretation.

Treatment of S-sensitive cells with both virginiamycin components induces a permanent suppression of their protein forming capacity. The mechanism by which virginiamycin $M$ stops protein synthesis has been elucidated; the inhibitor binds to the acceptor ' $A$ ' site of $50 \mathrm{~S}$ ribosomes and prevents donor and acceptor sites from functioning (Cocito \& Kaji, I97I). Unfortunately, no activity of virginiamycin $S$ was detected in cell-free systems nor was a synergistic action of $M$ and $S$ disclosed. However, the observation that factor $M$ forms an unstable complex with the $50 \mathrm{~S}$ ribosomal subunit, and that virginiamycin $\mathrm{S}$ stabilizes such a complex (Ennis, I97I) might account for the apparent inactivity of S factor in cell-free systems while explaining the synergistic effect of the two components.

The most intriguing finding is the opposite effect that virginiamycin $\mathrm{S}$ exerts on the M-mediated inhibition of protein synthesis, depending on the presence of the gene for $\mathrm{S}$ sensitivity. At the present time we have no plausible explanation for such effect.

Thanks are due to Mr F. Van Linden and Mr P. Rensonnet for invaluable help and to Professor G. Sokal and Mr C. Bellenot for use of Coulter Counters. 


\section{REFERENCES}

Cociтo, C. (1969a). Metabolism of macromolecules in bacteria treated with virginiamycin. Journal of General Microbiology 57, I79-194.

Cocito, C. $(1969 b)$. The action of virginiamycin on nucleic acid and protein synthesis in $B$. subtilis infected with bacteriophage 2 C. Journal of General Microbiology 57, 195-206.

CocrTo, C. (I97I). Formation and decay of polyribosomes and ribosomes during the inhibition of protein synthesis and recovery. Biochimie 53, 987-1000.

Cocito, C. (I973). Formation of ribosomal particles in virginiamycin sensitive and resistant mutants of B. subtilis. Biochimie (in the press).

Cocito, C., Bronchart, R. \& VAN Pel, B. (1972). Phenotypic and genotypic changes produced in eucaryotic cells by protein inhibitors. Biochemical and Biophysical Research Communications 46, I688-I 694.

Cociro, C. \& KAJI, A. (I97I). Virginiamycin M - a specific inhibitor of the acceptor site of ribosomes. Biochimie 53, 763-770.

ENNIS, H. L. (1965a). Inhibition of protein synthesis by polypeptide antibiotics. I. Inhibition in intact bacteria. Journal of Bacteriology 90, $1102-1108$.

ENNIS, H. L. (1965b). Inhibition of protein synthesis by polypeptide antibiotics. II. In vitro protein synthesis. Journal of Bacteriology 90, I I09-I I 19.

ENNIS, H. L. (197I). Interaction of vernamycin A with E. coli ribosomes. Biochemistry Io, 1265-1270.

Fan, D. P., Higa, A. \& Levinthal, C. (1964). Messenger RNA decay and protection. Journal of Molecular Biology 8, 2 IO.

Laskin, A. I. \& Chan, W. M. (1964). Inhibition by vernamycin A of amino acid incorporation in $E$. coli cell-free systems. Antimicrobial Agents and Chemotherapy 1963, 485-488.

Okamoto, K., Mudd, J. A., Mangan, J., Hang, W. M., Subbaiah, T. V. \& Marmur, J. (ig68). Properties of the defective phage of B. subtilis. Journal of Molecular Biology 34, 413-420.

PestKa, S. (1971). Inhibitors of ribosome functions. Annual Review of Biochemistry 40, 696-710.

Van Pel, B., Bronchart, R., Kebers, F. \& Cocito, C. (1972). Structure and function of cytoplasmic organelles in transiently and permanently bleached Euglena. Experimental Cell Research (in the press).

VAN PEL, B. \& Cocito, C. (I972). Formation of chloroplast ribosomes and ribosomal RNA in Euglena incubated with protein inhibitors. Experimental Cell Research (in the press).

VAZQUEZ, D. (I966). Studies on the mode of action of the streptogramin antibiotics. Journal of General Microbiology 42, 93-106.

VAzQuez, D. (1967). The streptogramin family of antibiotics. In Antibiotics, vol. I, p. 387. Edited by D. Gottlieb and P. D. Shaw. New York: Springer Verlag.

Yamaguchi, H. \& TANAKA, N. (I964). Selective toxicity of mikamycins, inhibitors of protein synthesis. Nature, London 20I, 499-50I. 